\title{
THE EFFICACY OF A PHYTOESTROGEN-RICH CHINESE MEDICINE ON SENILE OSTEOPOROSIS
}

\author{
NING GUO ${ }^{1}$, BINGLIANG LI ${ }^{2}$, XIAORUI JIANG ${ }^{3 *}$ \\ ${ }^{I}$ Training Center, Affiliated Hospital of Jining Medical University, Jining, Shandong, 272029, China \\ ${ }^{2}$ Joint Surgery Department, Affiliated Hospital of Jining Medical University, Jining, Shandong, 272029, China \\ ${ }^{3}$ Orthopedics Department, Yantai Yuhuangding Hospital, Yantai, Shandong, 264000, China a
}

*corresponding author: xiaorui_jayty@sina.com

Manuscript received: December 2017

\begin{abstract}
The aim of this study was to explore the potential therapeutic effect of a phytoestrogen-rich Chinese phytoterapeutics on senile osteoporosis. Sixty elderly osteoporosis patients admitted to Affiliated Hospital of Jining Medical University, Jining, Shandong, China from March 2016 to June 2017 were randomly divided into an experimental group (group A) and a control group (group B). Both groups received one tablet of $1.5 \mathrm{~g}$ calcium carbonate (ie $600 \mathrm{mg} \mathrm{Ca}^{2+}$ per tablet) plus 400 UI vitamin $\mathrm{D}_{3}$ per day, while group A also received Xianling Gubao capsules in the dose of three tablets twice a day. Before and after twelve weeks of administration, the changes of bone mineral density (BMD), serum calcium, serum phosphorus, alkaline phosphatase (AKP) and bone gla protein (BGP) levels were measured. There were no significant differences in BMD, serum calcium, serum phosphorus and AKP before treatment between group A and B $(p>0.05)$. After treatment, BMD and serum calcium increased, while serum phosphorus and AKP decreased significantly $(p<0.05)$. Compared with group $B$, the changes of each biomarker in group A were significantly improved after the treatment compared with group B $(p<0.05)$. Phytoestrogen-rich Chinese phytoterapeutic increased BMD and the level of blood calcium, decreased the level of blood phosphorus and AKP and showed to be a good natural adjuvant in the treatment of senile osteoporosis.
\end{abstract}

\section{Rezumat}

Scopul acestui studiu a fost de a cerceta efectul terapeutic al unui produs tradițional chinezesc bogat în fitoestrogeni, în osteoporoza senilă. Șaizeci de pacienți vârstnici cu osteoporoză au fost împărțiți aleatoriu într-un grup experimental (grupul A) și un grup de control (grupul B). Ambele grupuri au primit $1,5 \mathrm{~g}$ carbonat de calciu (600 $\mathrm{mg} \mathrm{\textrm {Ca } ^ { 2 + }}$ per comprimat) plus $400 \mathrm{UI}$ vitamină $\mathrm{D}_{3}$ pe zi, în timp ce grupul A a primit și Xianling Gubao, trei comprimate, de două ori pe zi. După 12 săptămâni de tratament s-au determinat modificările densității minerale osoase (DMO), calciului seric, fosforului și activitatea fosfatazei alcaline (PKA). După tratament, DMO și calciul seric au crescut comparativ cu valorile inițiale, în timp ce fosforul seric și PKA au scăzut semnificativ ( $p<0,05$ ). În comparație cu grupul $B$, modificările fiecărui parametru pentru grupul A au fost semnificativ îmbunătăţite după tratament $(\mathrm{p}<0,05)$. Produsul tradiţional chinezesc bogat în fitoestrogeni a crescut DMO și nivelul calciului din sânge, a scăzut nivelul fosforului și PKA, putând fi considerat un bun adjuvant în tratamentul osteoporozei senile.

Keywords: Xianling Gubao, senile osteoporosis, bone mineral density, bone metabolism index

\section{Introduction}

Osteoporosis is a systemic bone disease manifested as the decline of bone density and bone mass with changes in skeletal microstructure that lead to increased bone brittleness and high probability of fractures [19]. Osteoporosis can be classified by aetiology in postmenopausal osteoporosis, senile osteoporosis (that appear to elders above 70 years old) and idiopathic osteoporosis [11]. The aging of the population and increased exposure to chemicals, especially endocrine disruptors chemicals has made osteoporosis more likely to occur and the disease has gradually become a serious social problem [4, $5,15]$, having a high influence on people's life and economic burden for their families [17]. Oinuma et al. [13] conducted a three-years survey between
2004 and 2006 on the population from Sado, Japan, regarding the fracture risk and showed an increased incidence of spinal fractures, followed by femoral neck fractures, distal radius fractures and proximal humerus fractures. Different approaches for the treatment of senile osteoporosis currently exist but many of them determine side effects that limited their use especially in elder patients. The focus nowadays is on the discovery of new molecules, pharmaceutical formulations or plant extracts with less side effects that can improve the efficacy of the standard treatment $[14,16,22]$. By using rapamycin in elderly Sprague-Dawley male rats and observing its effect on autophagy of bone cells, Luo et al. [10] found that rapamycin-treated rats showed reduced apoptosis of osteocytes, suggesting that rapamycin might reduce the severity of age-related bone 
changes in the trabecular bone of elderly male rats. Yu et al. [23] treated vertebral compression fracture with Jintiange capsules, and showed that the vertebral body height, Cobb angle, bone mineral density, VAS (Visual Analogue Scale/Score) and Oswestry disability index were improved after the treatment, making it a good candidate as an adjuvant therapy after osteoporotic vertebral compression percutanous kyphoplasty (PKP). The Xianling Gubao capsules are orthopaedic phytotherapeutics which are mainly composed of Herba epimedii, Radix dipsaci, Fructus Psoraleae, Radix Rehmanniae, Radix salvia miltiorrhiza and Rhizoma anemarrhenae for the treatment of osteoporosis and osteoarthritis [20]. Wang et al. [18] made a systematic review of the literature regarding the efficacy and safety of Xianling Gubao capsules in treating osteoporosis. They identified 54 studies regarding the efficacy of the adjuvant administration of Xianling Gubao capsules in osteoporosis. This study aimed to evaluate the effect of Xianling Gubao capsules and standard Western treatment comprising an association of calcium carbonate, vitamin D3 and oligoelements for improving bone formation on senile osteoporosis patients, in order to provide theoretical and experimental basis for other options in the treatment of osteoporotic patients in the future.

\section{Materials and Methods}

Patients. Sixty elderly patients with senile osteoporosis (38 males and 22 females) admitted to the Affiliated Hospital of Jining Medical University, China from March 2016 to June 2017, with no medicine taking before or serious liver and kidney dysfunction, thyroid dysfunction, diabetes or other diseases, were included. The study was approved by the hospital's ethics committee and all the patients signed the informed consent to participate in the study. The 60 patients were divided into an experimental group (group A) and a control group (group B), 30 in each. In group A, there were 17 male patients and 13 female patients, with an average age of $(69.16 \pm 3.58)$ years old and an average course of disease of $(4.6 \pm 1.9)$ years. In group B, there were 21 male patients and 9 female patients, with an average age of $(67.95 \pm 3.05)$ years old and an average course of disease of $(4.7 \pm 2.3)$ years. There was no significant difference between the two groups in terms of sex ratio, average age and average course of disease $(p>0.05)$.

Group A received for 12 weeks the following treatment: one tablet of $1.5 \mathrm{~g}$ calcium carbonate (ie $600 \mathrm{mg} \mathrm{Ca}{ }^{2+}$ per tablet), $400 \mathrm{UI}$ vitamin $\mathrm{D}_{3}$ and Xianling Gubao capsules in a dose of 3 tablets twice a day [7].
Group B received for 12 weeks one tablet of $1.5 \mathrm{~g}$ calcium carbonate (ie $600 \mathrm{mg} \mathrm{Ca}{ }^{2+}$ per tablet) and 400 UI vitamin $\mathrm{D}_{3}$.

Efficacy evaluation. Before and at the end of the 12 weeks of treatment, the clinical symptoms of the two groups were assessed and the Bone Mineral Density (BMD) was determined using dual-energy X-ray absorptiometry [12].

The indexes of efficacy were as follows: (1) very effective: clinical symptoms were basically disappeared, BMD showed a certain degree of increase and the body movements were basically restored to the normal level; (2) effective: clinical symptoms weakened, BMD increased slightly and the body movements were improved; (3) ineffective: there was no significant change in the clinical symptoms, BMD and body movements before and after treatment, or the disease situation even worsened. The calculation formula of the total efficiency was as follows:

\section{Total efficiency $=$ (very effective cases + effective cases)/total cases}

Laboratory biomarkers: The blood calcium, blood phosphorus, and AKP (alkaline phosphatase) of the two groups were examined using a fully automatic biochemical analyser (Beckman Coulter, Inc., USA) before and after treatment. Bone gla protein (BGP) was measured using radioimmunoassay. Kits (Roche Diagnostics GmbH, Germany) were used. The data were compared both within groups and between groups.

Statistical processing. SPSS22.0 software was used and data were expressed as mean \pm standard deviation and compared by Student's t test. A value of $\mathrm{p}<0.05$ was considered statistical significant.

\section{Results and Discussion}

After the 12 weeks of treatment, the efficacy of the treatment in group A was $90.0 \%$ (27/30), with 22 patients in which the treatment was very effective, 5 patients in which the treatment was effective and 3 patients in which the treatment was ineffective. The efficacy of the treatment in group B was $73.3 \%$ (22/ 30), with 11 patients in which the treatment was very effective, 11 patients in which the treatment was effective and 8 patients in which the treatment was ineffective. There were significant differences between the two groups $(\mathrm{p}<0.05)$, as shown in Table I.

Comparison of BMD changes.

The BMD changes of the two groups after 12 weeks of treatment are shown in Table II. 
Comparison of the clinical efficiency of the two groups

\begin{tabular}{cccccc}
\hline Group & Number of cases & Very effective & Effective & Ineffective & Total efficacy (\%) \\
\hline A & 30 & 22 & 5 & 3 & 90.0 \\
B & 30 & 11 & 11 & 8 & 73.3 \\
p & & & & & 0.03 \\
\hline
\end{tabular}

Table II

Comparison of BMD and BGP changes of the two studied groups

\begin{tabular}{ccccccc}
\hline \multicolumn{3}{c}{ BMD } & \multicolumn{3}{c}{ BGP } \\
\hline \multirow{2}{*}{ Group } & $\begin{array}{c}\text { Before treatment } \\
\left(\mathrm{g} / \mathrm{cm}^{2}\right)\end{array}$ & $\begin{array}{c}\text { After treatment } \\
\left(\mathrm{g} / \mathrm{cm}^{2}\right)\end{array}$ & $\begin{array}{c}\mathrm{P} \\
\text { value }\end{array}$ & $\begin{array}{c}\text { Before treatment } \\
(\mu \mathrm{g} / \mathrm{L})\end{array}$ & $\begin{array}{c}\text { After treatment } \\
(\mu \mathrm{g} / \mathrm{L})\end{array}$ & $\begin{array}{c}\mathrm{p} \\
\text { value }\end{array}$ \\
\hline A & $0.672 \pm 0.141$ & $0.811 \pm 0.166^{* \#}$ & 0.02 & $31.32 \pm 3.12$ & $38.26 \pm 4.32^{* \#}$ & 0.01 \\
B & $0.665 \pm 0.125$ & $0.703 \pm 0.114^{\#}$ & 0.08 & $32.21 \pm 3.24$ & $34.16 \pm 4.17^{\#}$ & 0.09 \\
\hline
\end{tabular}

* significant differences within the group before and after treatment $(\mathrm{p}<0.05) ;{ }^{*}$ significant differences of group B $v s$ group A after treatment $(\mathrm{p}<0.05)$.

As shown in Table, it was a significant increase in the BMD levels in group A after the treatment compared with the level before the treatment, $0.891 \pm$ $0.166 \mathrm{~g} / \mathrm{cm}^{2}$ versus $0.672 \pm 0.141 \mathrm{~g} / \mathrm{cm}^{2}(\mathrm{p}<0.05)$. In group B there was an increase of the BMD levels after the treatment but did not reach the statistical significance, $0.773 \pm 0.114 \mathrm{~g} / \mathrm{cm}^{2}$ compared with $0.665 \pm 0.125 \mathrm{~g} / \mathrm{cm}^{2}(\mathrm{p}>0.05)$. Before the treatment there was no difference of the BMD between the two groups, but a significant difference was observed after the treatment $(\mathrm{p}<0.05)$. There was no significant difference of BGP levels between the two groups before treatment $(\mathrm{p}>0.05)$, but BGP levels in both groups increased after treatment from $31.32 \pm 3.12 \mu \mathrm{g} / \mathrm{L}$ to $38.26 \pm 4.32 \mu \mathrm{g} / \mathrm{L}$ in group $\mathrm{A}$ $(\mathrm{p}<0.05)$ and from $32.21 \pm 3.24 \mu \mathrm{g} / \mathrm{L}$ to $34.16 \pm$ $4.17 \mu \mathrm{g} / \mathrm{L}$ in group $\mathrm{B}(\mathrm{p}<0.05)$. The increase of BGP levels in group A was significantly higher than that in group B.

Blood calcium, blood phosphorus and AKP changes The blood calcium, blood phosphorus and AKP changes of the two groups after 12 weeks of treatment are shown in Table III.

Table III

Comparison of blood calcium, blood phosphorus and AKP changes between the two studied groups

\begin{tabular}{ccccccc}
\hline \multirow{2}{*}{ Group } & \multicolumn{2}{c}{ Blood calcium $(\mathrm{mmol} / \mathrm{L})$} & \multicolumn{2}{c}{ Blood phosphorus $(\mathrm{mmol} / \mathrm{L})$} & \multicolumn{2}{c}{ AKP $(\mathrm{U} / \mathrm{L})$} \\
\cline { 2 - 6 } & Before treatment & After treatment & Before treatment & After treatment & Before treatment & After treatment \\
\hline A & $1.98 \pm 0.34$ & $2.35 \pm 0.39^{*}$ & $1.91 \pm 0.32$ & $1.23 \pm 0.27^{*}$ & $162.87 \pm 16.49$ & $94.31 \pm 10.75^{*}$ \\
B & $1.95 \pm 0.41$ & $2.11 \pm 0.37^{* \#}$ & $1.88 \pm 0.42$ & $1.61 \pm 0.38^{* \#}$ & $165.66 \pm 15.83$ & $138.18 \pm 11.63^{* \#}$ \\
\hline
\end{tabular}

significant differences within the group before and after treatment $(\mathrm{p}<0.05)$; ${ }^{*}$ significant differences of group B $v s$ group A after treatment $(\mathrm{p}<0.05)$.

As shown in Table, the serum calcium in both groups increased after the treatment from $1.98 \pm 0.34$ $\mathrm{mmol} / \mathrm{L}$ to $2.35 \pm 0.39 \mathrm{mmol} / \mathrm{L}$ in group $\mathrm{A}(\mathrm{p}<0.05)$ and from $1.95 \pm 0.41 \mathrm{mmol} / \mathrm{L}$ to $2.11 \pm 0.37 \mathrm{mmol} / \mathrm{L}$ in group $B(p<0.05)$. The serum phosphorus in both groups decreased after the treatment, from $1.91 \pm 0.32 \mathrm{mmol} / \mathrm{L}$ to $1.23 \pm 0.27 \mathrm{mmol} / \mathrm{L}$ in group A $(\mathrm{p}<0.05)$ and from $1.88 \pm 0.42 \mathrm{mmol} / \mathrm{L}$ to $1.61 \pm 0.38 \mathrm{mmol} / \mathrm{L}$ after the treatment in group B $(\mathrm{p}<0.05)$. The AKP levels in both groups decreased after the treatments, in group A from $162.87 \pm 16.49$ $\mathrm{U} / \mathrm{L}$ to $94.31 \pm 10.75 \mathrm{U} / \mathrm{L}(\mathrm{p}<0.05)$ and in group $B$ from $165.66 \pm 15.83 \mathrm{U} / \mathrm{L}$ to $138.18 \pm 11.63 \mathrm{U} / \mathrm{L}$ $(p<0.05)$. In group A it was observed a significant improvement in all the three parameters compared to group $B(p<0.05)$.

Osteoporosis is a systemic bone metabolic disease [1], in which the bone tissue is deteriorated, the bone density is decreased, and the bone fragility is increased, that leads to an increase risk of fracture.
Nowadays, the treatment of osteoporosis mainly relies on the use of bisphosphonates and calcitonin [2], but the side effects of these drugs can determine other problems. Therefore, finding more suitable medicines for the treatment of osteoporosis is of high significance. Calcium carbonate associated with vitamin D3 can provide calcium to the human body, on one hand, and on the other vitamin D3 can induce the production of calcium-binding protein, thereby enhancing the intestinal absorption of calcium and promoting the formation of osteoblasts and bone substances as well as reducing the risk of bone loss. However, the effects of this association alone are not ideal, and they are commonly used in combination with other medicines to strengthen the therapeutic effect.

The Xianling Gubao capsules are made from the Chinese medicinal herbs of Herba epimedii, Radix dipsaci, Fructus Psoraleae, Radix Rehmanniae, Radix salvia miltiorrhiza and Rhizoma anemarrhenae. This 
combination has the effect of nourishing the liver and the kidney, activating the blood circulation and strengthening the bones [3]. Herba epimedii acts on tendons and bones. The active ingredients are flavonoidic compounds, which can prevent osteoporosis by inhibiting the activity of osteoclasts [8], can promote the secretion of sex hormones and delay gonadal tissue aging. Radix dipsaci has the effect of nourishing the liver, strengthening the bones, stabilizing and healing fractures [9]. Salvia miltiorrhiza has the effect of ameliorating blood stasis and inducing menstruation to relieve menalgia. With all these Chinese medicine as ingredients, Xianling Gubao capsules can regulate body metabolic balance, accelerate the proliferation and differentiation of osteocytes, inhibit osteoclasts, increase bone density and bone mineral content, modulate levels of sex hormones, so as to reduce the bone loss [22].

As shown in the experimental results, the total treatment efficiency and BMD of group A was significantly higher than group $B(p<0.05)$. After twelve weeks of treatment, BMD and BGP of group A were significantly higher than group B $(p<0.05)$, indicating that Xianling Gubao could improve bone density and BGP levels. Bone mineral density can reflect about $70 \%$ of the bone strength and is currently an important indicator of bone health. BGP plays an important role in regulation of bone calcium metabolism and has important values to the diagnosis of osteoporosis, therefore the increase of the two indicators can indicate Xianling Gubao proved good efficacy in the treatment of osteoporosis. The serum calcium increased and serum phosphorus and AKP decreased in group A, being significant different compared with group B $(p<0.05)$, which indicates that Xianling Gubao capsules can increase the levels of serum calcium and lower serum phosphorus levels and AKP and promote bone repair.

One percent of the calcium in the human body is present in the blood, in an ionic state, known as blood calcium, which is very different from the calcium found in the bones. Blood calcium and bone calcium can be converted into each other in the body. Bone calcium can enter into the blood due to osteoclasts and blood calcium can be converted to bone calcium by osteoblasts, which forms the physiological balance of body calcium. The determination of blood calcium content can not only reflect the calcium content of human body but also may show the condition of bone mineral metabolism. Phosphorus accounts for only one percent of the body's weight, and four-fifths of the phosphorus is in the form of hydroxyapatite, which is found in the bones and teeth. Phosphorus, which is present in bone minerals, maintains the body's mechanical strength, i.e., the bone strength. AKP is an important protein present in the plasma membranes and also involved in bone metabolism, its main physiological function being to hydrolyse the phosphate in the process of osteogenesis to provide phosphoric acid for the deposition of hydroxyapatite and hydrolyse pyrophosphate to remove its inhibiting effect on bone salts in order to enhance osteogenesis. Therefore, AKP is an important indicator of osteoblasts activity.

\section{Conclusions}

The clinical efficacy of patients who were treated by Xianling Gubao capsules was significantly superior to that of patients who were not. Xianling Gubao capsules could significantly improve levels of BMD and BGP. Xianling Gubao capsules could regulate the blood calcium level, reduce blood phosphorus and AKP levels, and promote bone repair.

As our data showed, Xianling Gubao capsules has a favourable efficacy in the treatment of senile osteoporosis. It can effectively improve bone metabolism, reduce loss of bone mass, improve osteoporosis, and enhance quality of life; hence it is worth clinical promotion.

\section{References}

1. An J, Yang H, Zhang Q, Liu CC, Zhao JJ, Zhang LL, Natural products for treatment of osteoporosis: The effects and mechanisms on promoting osteoblast-mediated bone formation. Life Sci., 2016; 147: 46-58.

2. Chen BL, Xie DH, Zheng ZM, Lu WW, Ning CY, Li YQ, Li FB, Liao WM, Comparison of the effects of alendronate sodium and calcitonin on boneprosthesis osseointegration in osteoporotic rats. Osteoporos Int., 2011; 22(1): 265-270.

3. Chen W, Du SY, Wu Q, Wu HC, Chen XL, Comparative study on dissolution of Xianling gubao capsules prepared by different processes. China Journal of Chinese Materia Medica, 2010; 35(12):1541-1546.

4. Ciesielczuk N, Glibowski P, Szczepanik J, Awareness of factors affecting osteoporosis obtained from a survey on retired Polish subjects. Roczniki Panstwowego Zakladu Higieny, 2014; 68(2): 147-53.

5. Duncan R, Francis RM, Jagger C, Kingston A, McCloskey E, Collerton J, Robinson L, Kirkwood TB, Birrell F, Magnitude of fragility fracture risk in the very old - are we meeting their needs? The Newcastle 85+ Study. Osteoporos Int., 2015; 26(1): 123-130.

6. Fathilah S, Abdullah S, Mohamed N, Shuid A, Labisia pumila prevents complications of osteoporosis by increasing bone strength in a rat model of postmenopausal osteoporosis. EvidenceBased Complementray and Alternative Medicine, 2012; 2012: 155-237.

7. Geng JL, Dai Y, Yao ZH, Qin ZF, Wang XL, Qin L, Yao XS, Metabolites profile of Xian-Ling-Gu-Bao capsule, a traditional Chinese medicine prescription, in rats by ultra performance liquid chromatography 
coupled with quadrupole time-of-flight tandem mass spectrometry analysis. Journal of Pharmaceutical \& Biomedical Analysis, 2014; 96(6): 90-103.

8. Hsieh TP, Sheu SY, Sun JS, Chen MH, Icariin inhibits osteoclast differentiation and bone resorption by suppression of MAPKs/NF-kB regulated HIF1a and PGE(2) synthesis. Phytomedicine, 2011; 18(3): 176-185.

9. Huang QC, Chu YL, He XH, Huang RY, Regulatory roles of compound danshen in the downstream path of cyclooxygenases in rheumatoid arthritis patients' synovium. Zhongguo Zhong Xi Yi Jie He Za Zhi, 2013; 33(10): 1416-1419.

10. Luo D, Ren H, Li T, Lian K, Lin DS, Rapamycin reduces severity of senile osteoporosis by activating osteocyte autophagy. Osteoporos Int., 2015; 27(3): 1-9

11. Marcucci G, Brandi ML, Kyphoplasty and vertebroplasty in the management of osteoporosis with subsequent vertebral compression fractures. Clin Cases Miner Bone Metab, 2010; 7(1): 51-60.

12. Murthy PSN, Tripathi A, Singh R, Current Trends in the Clinical Utility of Bone Mineral Density to Assess Fracture Risk in Postmenopausal Osteoporosis. Advances in Medicine and Biology, 2010; 8: 165-190.

13. Oinuma T, Sakuma M, Endo N. Secular change of the incidence of four fracture types associated with senile osteoporosis in Sado, Japan: the results of a 3year survey. J Bone Miner Metab., 2010; 28(1): 55.

14. Pantea-Stoian A, Pițuru SM, Hainăroșie R, Andronache LF, Ginghină O, Serafinceanu C, Testosterone therapy, new opportunities in diabetes mellitus. Farmacia, 2018; 66(1): 1-7.

15. Petrakis D, Vassilopoulou L, Mamoulakis C, Psycharakis C, Anifantaki A, Sifakis S, Docea AO, Tsiaoussis J, Makrigiannakis A, Tsatsakis AM, Endocrine disruptors leading to obesity and related diseases. Int $J$ Environ Res Public Health., 2017; 14(10): 1-18.
16. Saramet G, Radulescu FS, Miron DS, Barbuceanu SF, Stanescu AA, Vlaia L, Pituru S, Lupuliasa D, Study describing the formulation and the release of some active pharmaceutical ingredients from HPMC hydrophilic matrix tablets. Note I. Farmacia, 2017; 65(5): 690-697.

17. Taerel AE, Rosenberg L, Nicolescu T, Ethics and equity in providing pharmaceutical assistance to the population. Revista Romana de Bioetica, 2010; 8(1): 150-154.

18. Wang GQ, Liao X, Zhang YL, Xie YM, Systemic evaluation and Meta-analysis of Xianling Gubao capsule in treatment of primary osteoporosis in randomized controlled trials. Zhongguo Zhong Yao Za Zhi, 2017; 42(15): 2829-2844.

19. Wekre LL, Eriksen EF, Falch JA, Bone mass, bone markers and prevalence of fractures in adults with osteogenesis imperfecta. Arch Osteoporos., 2011; 6(12): 31-38.

20. Wu J, Wen L, Wu Y, Shen Q, Han Y, Effects of Xianling Gubao capsules for the treatment of bone loss induced by glucocorticoid. China J Orthopaedics and Traumatology, 2009; 22(3): 193-195.

21. Wu ZH, Zhu X, Xu CK, Chen YJ, Zhang L, Zhang $\mathrm{CL}$, Effect of xianling gubao capsules on bone mineral density in osteoporosis patients. $J$ Biolo Regul Homeost Agents, 2017; 31(2): 359-364.

22. Ye CF, Pan YM, Zhou H, Regulation of vitamin D receptor and genistein on bone metabolism in mouse osteoblasts and the molecular mechanism of osteoporosis. J Biol Regul Homeost Agents, 2018; 32(3): 497-505.

23. Yu LJ, Wen JX, Song HP, Liu H, Application of Jintian'ge capsule in treatment of vertebral compression fracture in senile osteoporosis patients. China Journal of Chinese Materia Medica, 2015; 40(5): 981-984. 